\title{
PENGARUH KOMPETENSI, MOTIVASI, DAN LINGKUNGAN KERJA TERHADAP KINERJA DOSEN SEKOLAH TINGGI EKONOMI SYARIAH (STES) TUNAS PALAPA LAMPUNG TENGAH (Studi berdasarkan Persepsi Mahasiswa STES Tunas Palapa Lampung Tengah)
}

\author{
Trisnowati Josiah \\ Univrsitas Sang Bumi Ruwa Jurai \\ trisnowatij@gmail.com
}

\begin{abstract}
Abstrak. Penelitian ini bertujuan untuk mengetahui pengaruh variabel kompetensi terhadap kinerja dosen, mengetahui pengaruh motivasi terhadap kinerja dosen, mengetahui pengaruh lingkungan kerja terhadap kinerja dan mengetahui secara bersama-sama pengaruh variabel kompetensi, motivasi, dan lingkungan kerja terhadap kinerja dosen. Penelitian ini dilakukan melalui metode penelitian deskriptif kuantitatif dengan kuesioner sebagai alat pengumpulan data melalui bantuan google form, dengan jumlah data responden sebanyak 56 mahasiswa, menggunakan uji statistik, dan pengujian hipotesis. Hasil penelitian ini menunjukkan bahwa variabel kompetensi, motivasi dan lingkungan kerja secara simultan berpengaruh terhadap kinerja dosen STES Tunas Palapa. Variabel kompetensi terhadap kinerja dosen berpengaruh secara parsial, variabel motivasi terhadap kinerja dosen berpengaruh secara parsial dan variabel lingkungan kerja terhadap kinerja dosen berpengaruh secara parsial.
\end{abstract}

Kata kunci: Kinerja, Kompetensi, Motivasi, Lingkungan Kerja

\section{THE EFFECT OF COMPETENCE, MOTIVATION, AND WORK ENVIRONMENT ON THE PERFORMANCE OF LECTURERS OF SHARIA ECONOMIC HIGH SCHOOL (STES) TUNAS PALAPA LAMPUNG CENTRAL (Study based on Student Perceptions of STES Tunas Palapa, Central Lampung)}

\author{
Trisnowati Josiah \\ Sang Bumi Ruwa Jurai Univrsity \\ trisnowatij@gmail.com
}

\begin{abstract}
This study aims to determine the effect of competency variables on lecturer performance, determine the effect of motivation on lecturer performance, determine the effect of work environment on performance and jointly determine the effect of competence, motivation, and work environment variables on lecturer performance. This research was conducted through a quantitative descriptive research method with a questionnaire as a data collection tool through the help of google form, with the number of respondent data as many as 56 students, using statistical tests and hypothesis testing. The results of this study indicate that the variables of competence, motivation and work environment simultaneously affect the performance of STES Tunas Palapa lecturers. The competence variable on lecturer performance has a partial effect, the motivation variable on lecturer performance has a partial effect and the work environment variable on lecturer performance has a partial effect.
\end{abstract}

Keywords: Performance, Competence, Motivation, Work Environment 


\section{PENDAHULUAN}

Dalam mengikuti perkembangan era saat ini untuk mencapai tujuan perguruan tinggi sesuai dengan Undang-undang Nomor 21 tahun 2003 Tentang sistem pendidikan Nasional menyebutkan bahwa tujuan pendidikan nasional adalah untuk mengembangkan potensi peserta didik agar menjadi manusia yang beriman dan bertakwa kepada Tuhan Yang Maha Esa, berakhlak mulia, sehat, berilmu, cakap, kreatif, mandiri, dan menjadi warga negara yang demokratis serta bertanggung jawab (Asmaroini, 2016; Hendriana \& Jacobus, 2017; Sumardi, 2018). Dapat disimpulkan tujuan perguruan tinggi adalah menyiapkan generasi bangsa agar mempunyai kualitas akademik dan intelektual yang baik sehingga dapat menguasai ilmu pengetahuan dan teknologi, serta menyiapkan calon-calon pemimpin masa depan yang berwawasan luas dan mampu menjawab tantangan bangsa dalam persaingan global yang semakin tajam (Wulandari, 2019). Dalam mencapai dan menciptakan sumber daya manusia yang sesuai dengan kriteria di atas, perguruan tinggi harus terlebih dahulu memiliki mutu pendidikan yang baik (Muslim et al., 2020).

Mutu pendidikan yang baik sangatlah bergantung pada proses pembelajaran yang diberikan oleh tenaga pendidik yang akan tercermin dari bagaimana seorang tenaga pendidik tersebut melaksanakan peran dan tugasnya. Seperti yang kita ketahui pada umumnya bahwa mahasiswa akan menerima dan berinteraksi langsung dengan tenaga pendidik sehingga menjelaskan bahwa kinerja seorang tenaga pendidik (dosen) merupakan faktor yang menentukan pencapaian mutu pendidikan (Mukhsin, 2019).

Dosen merupakan salah satu komponen esensial dalam suatu sistem pendidikan di perguruan tinggi (Artaye \& Wintoro, 2017; Muslihudin et al., 2017). Peran, tugas, dan tanggung-jawab dosen sangat bermakna dalam mewujudkan tujuan pendidikan nasional, yaitu mencerdaskan kehidupan bangsa, meningkatkan kualitas sumber daya manusia meliputi kualitas iman dan takwa, akhlak mulia, dan penguasaan ilmu pengetahuan baik segi teknologi dan budaya, serta mewujudkan masyarakat yang maju, adil, makmur dan beradab (Andoyo et al., 2017; Muslihudin et al., 2017).

Dilihat dalam pelaksanaan dharma pendidikan dan pengajaran dosen adalah seseorang berdasarkan pendidikan dan keahliannya yang memiliki tugas utama mengajar. Hal ini dijelaskan dalam pasal 1 Ayat 2 dalam Undang-Undang Guru dan Dosen Nomor 14 Tahun 2005, dosen adalah pendidik profesional dan ilmuwan dengan tugas utama mentransformasikan, mengembangkan, dan menyebarluaskan ilmu pengetahuan, teknologi, dan seni melalui pendidikan, penelitian, dan pengabdian kepada masyarakat (Dewi et al., 2020).

Berdasarkan undang-undang tersebut dosen harus memiliki kinerja yang baik dalam bekerja. Dalam menjalankan tugasnya untuk mencapai kinerja yang baik hal itu dapat dilihat dari beberapa faktor, antara lain faktor kompetensi, motivasi dan lingkungan kerja dosen tersebut. Kinerja setiap dosen perlu ditingkatkan secara terus-menerus agar dosen selalu tanggap terhadap perkembangan ilmu pengetahuan dan perkembangan teknologi sehingga dapat memberikan kualitas pendidikan yang baik kepada para mahasiswa.

Hal itu pula yang diliat oleh Sekolah Tinggi Ekonomi Syariah (STES) Tunas Palapa sebagai bagian dari sistem pendidikan nasional yang perlu terus didorong untuk meningkatkan 
pertumbuhan, peranan, tanggung-jawab dan mutu pendidikan dengan tetap mengindahkan ciri khas perguruan tinggi swasta yang bersangkutan serta syaratsyarat pendidikan secara umum salah satunya melalui kinerja dosen. Karena kinerja dosen merupakan salah satunya faktor penentu keberhasilan proses belajar dan mengajar di perguruan tinggi selain kemampuan mahasiswa dan keantusiasan mahasiswa (Nurmalasari, 2019).

Kinerja dosen pada suatu perguruan tinggi merupakan perilaku nyata yang ditampilkan setiap dosen sebagai prestasi kerja yang dihasilkan oleh dosen tersebut sesuai dengan peranannya (Rismayanti et al., 2018). Untuk dapat menentukan kualitas dan penilaian kinerja dosen perlu adanya analisa yang jelas pada faktor-faktor yang mempengaruhinya. Kinerja dosen merupakan suatu hal yang sangat penting dalam upaya mencapai tujuan lembaga perguruan tinggi.

Di dalam dunia yang kompetitif dan mengglobal setiap perguruan tinggi, seperti STES Tunas Palapa memerlukan kinerja dosen yang tinggi guna mencapai visi misi serta tujuan dan menyelenggarakan kegiatan tri dharma perguruan tinggi yang berkualitas dan relevan sesuai dengan kebutuhan masyarakat. Mengingat STES Tunas Palapa merupakan sekolah tinggi swasta yang baru mulai beroperasi sejak tahun 2018 maka semakin sangat membutuhkan peran serta oleh seluruh karyawan dan civitasnya dalam menjalani kegiatan aktivitas perguruan tinggi guna mampu dapat bertahan dan ikut bersaing dengan perguruan tinggi lainnnya.

Selain dari kondisi STES Tunas Palapa yang baru mulai berdiri, hal yang perlu diperhatikan pada STES Tunas Palapa sesuai dengan tri dharma perguruan tinggi dan harus dilaksanakan oleh dosen yaitu pada bidang pengajaran, penelitian dan juga pengabdian kepada masyarakat. Dalam bidang pengajaran dapat dilihat dari faktor kompetensi yang dimiliki oleh dosen STES Tunas Palapa. Hal ini dapat dilihat bahwa sebagian besar tenaga pendidik yang ada belum professional dan berkompeten di bidangnya dikarenakan tenaga pendidik yang baru pertama kali melakukan proses mengajar setelah menyelesaikan program studi sehingga masih memiliki banyak kekurangan dalam bidang pengalaman mengajar dan pemahaman akan cara penyampaian materi maupun tugas yang masih belum sebaik dosen yang professional. Masalah tersebut menyebabkan penyampaian materi kepada mahasiswa kurang baik dan mahasiswa pun kurang memahami materi sehingga pada akhirnya menimbulkan mahasiswa yang lebih banyak mencari materi dari situs online dibandingkan memahami penjelasan dari dosen tersebut secara langsung, itu dapat dilihat dari banyaknya mahasiswa yang terlihat dan kedapatan saat mengunakan smartphone disaat ujian berlangsung guna mencari jawaban. Hal ini mengartikan bahwa hasil dari segala penjalasan dosen selama ini masih belum bisa mereka pahami dan mengerti.

Kemudian kurangnya motivasi instrinstik yang ada pada dalam diri dosen tersebut sebagai kekuatan pendorong yang akan membantu dirinya dalam melaksanakan tanggungjawabnya dan mencapai tujuan dalam karirnya. Salah satu tanggungjawab seorang dosen dalam melaksanakan tri dharma adalah tentang penelitian yang harus ia lakukan, dalam hal ini dosen STES Tunas Palapa memiliki kekurangan yang terlihat pada dosen STES Tunas Palapa yang sampai saat ini banyak yang belum membuat jurnal ataupun penelitian yang sebenarnya merupakan kewajibannya dari tri dharma pendidikan yang sebetulnya akan bermanfaat dalam jenjang karirnya.

Selain itu, kondisi ini diperparah dengan kurangnya motivasi kerja yang berasal dari luar diri dosen tersebut yang 
tercermin dari sikap dosen dalam memenuhi tanggungjawab dan tugas seperti halnya pada pihak bagian akademik dengan seringnya terjadi keterlambatan penyerahan nilai oleh dosen sehingga membuat terganggunya proses akademik bahkan berubahnya jadwal pengumuman hasil ujian mahasiswa.

Selain itu kondisi non fisik dari lingkungan kerja juga bermasalah, banyak dosen STES Tunas Palapa yang belum melaksanakan tugas tri dharma di bidang pengabdian kepada masyarakat tersebut yang seharusnya dapat melibatkan peran serta mahasiswa didalamnya. Dalam faktor lingkungan kerja berdasarkan kondisi fisik dapat juga terlihat dari kurangnya pemanfaatan penggunaan fasilitas sarana dan prasarana dalam mengajar sehingga menimbulkan dampak penyampaian materi yang kurang efektif kepada mahasiswa. Tidak hanya itu, tidak banyak juga dosen yang terlambat dalam disiplin kehadiran dikarenakan faktor jarak mengajar dan rumah yang terbilang cukup jauh dan juga tidak jarang dosen yang tidak menghadiri kegiatan belajar dan mengajar tetapi hanya menyerahkan tugas dan pengajaran melalui asisten dosen dikarenakan mereka memiliki pekerjaan lain selain mengajar di STES Tunas Palapa.

Oleh karena itu perlu dilakukan sebuah penyelesaian terhadap masalah yang dihadapi oleh STES Tunas Palapa dengan mengadakan evaluasi terhadap kinerja dosen. Untuk mengetahui dosen STES Tunas Palapa yang memiliki kinerja baik adalah melalui evaluasi dari beberapa faktor yang dapat dijadikan instrumen penilaian kinerja sehingga dapat diketahui mana dosen yang mampu melaksanakan tugas secara baik sesuai dengan tridharma perguruan tinggi.

Evaluasi kinerja dosen pada STES Tunas Palapa diharapkan akan membuat STES dapat mengetahui dan mengendalikan kelemahan serta memperbaiki segala kekurangan sehingga dapat mencapai visi-misi, tujuan STES Tunas Palapa dan menciptakan kualitas SDM yang lebih unggul serta mampu memajukan STES Tunas Palapa menjadi perguruan tinggi swasta yang mampu bersaing dengan perguruan tinggi lainnya.

Penelitian sejenis sudah pernah dilakukan, antara lain penelitian oleh Manik \& Syafrina mengenai pengaruh kompetensi terhadap kinerja dosen (Manik \& Syafrina, 2018). Selain itu, penelitian oleh Yunarti mengenai pengaruh motivasi kerja terhadap kinerja dosen dan karyawan (Yunarti, 2017). Ada pula penelitian mengenai pengaruh kompetensi, kepemimpinan, dan lingkungan kerja terhadap kinerja dosen yang dilakukan oleh al-Qadri (Al-Qadri, 2019). Penelitian oleh Rosmaini \& Tanjung mengenai pengaruh kompetensi, motivasi, dan kepuasan kerja terhadap kinerja karyawan (Rosmaini \& Tanjung, 2019). Dan yang terakhir, penelitian oleh Rini, et.al mengenai pengaruh kompetensi, motivasi, dan lingkungan kerja terhadap kinerja karyawan PT Pos Indonesia (Persero) (Rini et al., 2018).

Berdasarkan dari penelitian sebelumnya, belum ada penelitian yang meneliti mengenai pengaruh kompetensi, motivasi, dan lingkungan kerja terhadap kinerja dosen. Hal tersebutlah yang menjadi unsur kebaruan pada penelitian kali ini.

Dari pengamatan inilah, guna mencapai kemajuan dan integritas serta seluruh tujuan dalam memperbaiki dan memajukan STES Tunas Palapa, dilakukan penelitian dengan tujuan mengetahui pengaruh variabel kompetensi terhadap kinerja dosen, mengetahui pengaruh motivasi terhadap kinerja dosen, mengetahui pengaruh lingkungan kerja terhadap kinerja dan mengetahui secara bersama-sama pengaruh variabel kompetensi, motivasi, dan lingkungan kerja terhadap kinerja dosen. Hal ini dilakukan untuk memperoleh temuan-temuan yang 
bisa dijadikan masukan (feedback) tidak hanya bagi STES Tunas Palapa namun juga bagi dosen dalam rangka mewujudkan tindakan yang positif menuju peningkatan budaya kerja yang lebih baik dan lebih professional.

\section{TINJAUAN TEORITIS}

\section{Kinerja}

Keberhasilan suatu organisasi dipengaruhi oleh kinerja (job performance) sumber daya manusia (SDM) nya (Teguh \& Julianto, 2020). Sumber daya manusia yang berkualitas akan turut memajukan organisasi, untuk itu setiap perusahaan akan berusaha untuk meningkatkan kinerja pegawai dalam mencapai tujuan organisasi yang telah ditetapkan. Kinerja merupakan kegiatan yang telah dicapai seseorang tenaga kerja dalam melaksanakan tugas dan pekerjaan yang di berikan kepadanya (Winarsih, 2018). Kinerja yang baik akan dipengaruhi oleh dua hal yaitu tingkat kemampuan dan motivasi kerja yang baik, itu artinya kemampuan seseorang dipengaruhi oleh pemahamannya atas jenis pekerjaan dan keterampilan melakukannya, oleh karenanya seseorang harus dapat meningkatkan kemampuan dan keterampilannya. Selain itu konstribusi motivasi kerja terhadap kinerja tidaklah dapat diabaikan. Meskipun kemampuan karyawan sangat baik apabila motivasi kerjanya rendah, sudah tentu kinerjanya juga akan rendah.

\section{Kompetensi}

Secara umum, kompetensi dapat dipahami sebagai sebuah penggabungan antara keterampilan (skill), attribut personal, dan pengetahuan (knowledge) yang tercermin melalui perilaku kerja (job behaviour) yang dapat diamati, diukur, dan dievaluasi (Muizu \& Sule, 2017). Kompetensi dibedakan menjadi dua tipe yaitu, soft competency atau jenis kompetensi yang berkaitan erat dengan kemampuan untuk mengelola proses pekerjaan, hubungan antar manusia serta membangun interaksi dengan orang lain dan hard competency atau jenis kompetensi yang berkaitan dengan kemampuan fungsional atau teknis suatu pekerjaan.

\section{Motivasi}

Secara umum motivasi dapat diartikan sebagai suatu tujuan atau pendorong, dengan tujuan sebenarnya tersebut yang menjadi gaya penggerak utama bagi seseorang dalam berupaya dalam mendapatkan atau mencapai apa yang diinginkan baik itu secara positif ataupun negatif (Eka, 2021). Adapun istilah dalam pengertian motivasi berasal dari kata bahasa inggris yakni motivation. Namun dalam bahasa melayu kata motive juga digunakan dalam kata motif yang berarti tujuan atau segala upaya untuk mendorong seseorang dalam melakukan sesuatu (Wahyudi \& Tupti, 2019). Selain itu secara ringkas pengertian motivasi merupakan suatu perubahan yang terjadi pada diri seseorang yang muncul adanya gejala perasaan, kejiwaan dan emosi sehingga mendorong individu untuk melakukan atau bertindak sesuatu yang disebabkan karena kebutuhan, keinginan dan tujuan.

Selain itu motivasi terbentuk dari sikap (attitude) seorang pegawai dalam menghadapi situasi (Situation) kerja (Aldi \& Susanti, 2019). Motivasi merupakan kondisi yang menggerakkan diri pegawai yang terarah untuk mencapai tujuan organisasi (Sugiono et al., 2021). Sikap mental merupakan kondisi mental yang mendorong diri pegawai untuk berusaha mencapai prestasi kerja secara maksimal. Sikap mental seorang pegawai harus sikap mental yang siap secara psikofisik (sikap secara mental, fisik, tujuan dan situasi). Artinya seorang pegawai harus siap mental, 
mampu secara fisik, memahami tujuan utama dan target kerja yang akan dicapai serta mampu memanfaatkan dan menciptakan situasi kerja (Harend et al., 2020).

\section{Lingkungan Kerja}

Lingkungan kerja merupakan segala sesuatu yang ada di sekitar pegawai yang dapat mempengaruhi diri pegawai dalam menjalankan tugas (Siagian \& Khair, 2018). Lingkungan kerja merupakan salah satu faktor penting dalam menciptakan kinerja karyawan (Adha et al., 2019) dan menjadi penyebab dari keberhasilan dalam melaksanakan suatu pekerjaan, tetapi juga dapat menyebabkan suatu kegagalan dalam pelaksanaan suatu pekerjaan, karena lingkungan kerja dapat mempengaruhi pekerja, terutama lingkungan kerja yang bersifat psikologis. Sedangkan pengaruhnya itu sendiri dapat bersifat positif dan dapat bersifat negatif (Mulia \& Saputra, 2021).

Menurut laporan tim produktifitas International Labour Office (ILO), hal pertama yang harus diusahakan untuk memperbaiki kinerja karyawan adalah menjamin agar karyawan dapat melaksanakan tugasnya dalam keadaan yang memenuhi syarat, sehingga mereka dapat melaksanakan tugasnya tanpa mengalami ketegangan-ketegangan, atau dengan kata lain sebuah perusahaan harus menyediakan lingkungan yang berkualitas agar para karyawannya nyaman sehingga akan meningkatkan produktivitas kerja (Handayani \& Hati, 2018).

$$
\text { Lingkungan }
$$

kerja dapat mempengaruhi emosi pegawai (Sunarsi et al., 2020), jika pegawai menyenangi lingkungan kerja dimana ia bekerja, maka pegawai tersebut akan betah di tempat bekerjanya untuk melakukan aktivitas sehingga waktu kerja dipergunakan secara efektif dan optimal prestasi kerja pegawai juga tinggi. Lingkungan kerja tersebut mencakup hubungan kerja yang terbentuk antara sesama pegawai dan hubungan kerja antar bawahan dan atasan serta lingkungan fisik tempat pegawai bekerja

\section{METODE PENELITIAN}

Metode yang digunakan dalam penelitian ini adalah metode penelitian kuantitatif. Subjek dalam penelitian ini adalah dosen Sekolah Tinggi Ekonomi Syariah (STES) Tunas Palapa yang terletak di Lampung Tengah. Objek pada penelitian ini adalah 19 dosen STES Tunas Palapa yang merupakan dosen dari jurusan ekonomi syariah dan perbankan syariah.

Teknik pengumpulan data akan dilakukan melalui persepsi mahasiswa berdasarkan kinerja dosen yang dirasakan mahasiswa selama menjalankan proses pendidikan dan pembelajaran dengan menggunakan pengisian angket pernyataan. Kuisioner akan dibagikan kepada responden yang merupakan mahasiswa STES Tunas Palapa yang berjumlah 56 mahasiswa. Data yang didapat selanjutnya dianalisis untuk melihat ada tidaknya pengaruh faktor-faktor terhadap kinerja dosen STES Tunas Palapa.

\section{HASIL DAN PEMBAHASAN}

Berdasarkan data yang telah didapat, jawaban responden direkapitulasi kemudian dianalisis untuk mengetahui tingkat variabel kompetensi, motivasi, lingkungan kerja dan kinerja dosen di STES Tunas Palapa, Lampung Tengah. Tingkat variabel diklasifikasikan menggunakan skala likert dengan bobot nilai tertinggi adalah 4 dan nilai terendah adalah 1 . Lebih jelasnya peneliti membuat tiga tingkat kategori dengan klasifikasi sebagai berikut:

Skor rata-rata $1-2$ : Tingkat variabel rendah

Skor rata-rata 2-3 : Tingkat variabel sedang 
Skor rata-rata 3-4 : Tingkat variabel tinggi

Dari data yang didapat, maka deskripsi serta hasil pengukuran terhadap variabel kompetensi, motivasi, lingkungan kerja, dan kinerja dosen adalah sebagai berikut:

Tabel 1

Deskripsi Variabel

\begin{tabular}{clc}
\hline No. & \multicolumn{1}{c}{ Variabel } & $\bar{x}$ \\
\hline 1. & Kompetensi (X1) & 3,36 \\
2. & Motivasi (X2) & 3,46 \\
3. & Lingkungan Kerja (X3) & 3,43 \\
4. & Kinerja Dosen (Y) & 3,43 \\
\hline
\end{tabular}

Sumber: Data Primer, 2020

Berdasarkan Tabel 1, diperoleh nilai seluruh rata-rata variabel berada pada kategori 3-4, artinya seluruh variable yang dianalisis dalam kategori tinggi. Berikut rekapitulasi frekuensi dan persentase responden terhadap masing-masing variable.

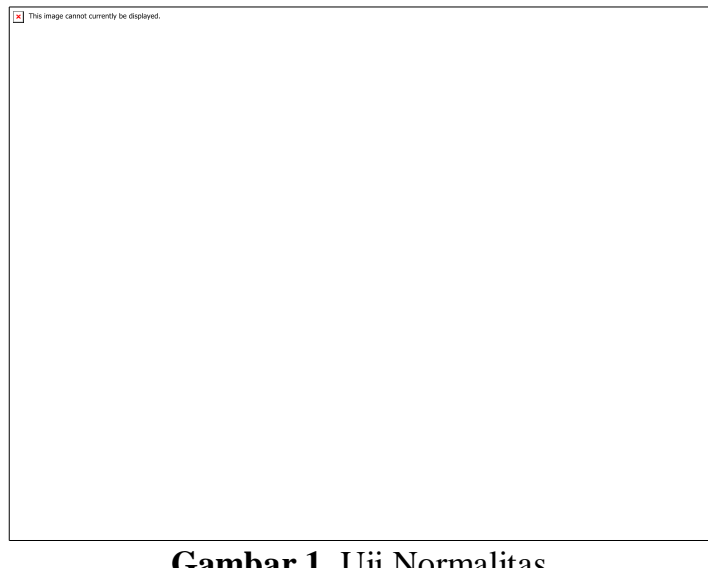

Gambar 1. Uji Normalitas

Berdasarkan hasil uji normalitas di atas, terlihat bahwa ini nilai Asymp. Sig. (2-tailed) > 0,05). Berdasarkan hasil tersebut maka dapat disimpulkan bahwa model regresi telah memenuhi asumsi normalitas. Selanjutnya dilanjutkan Uji Heteroskedastisitas untuk menilai apakah ada ketidaksamaan varian dari residual untuk semua pengamatan pada model. Berikut hasilnya:

Tabel 2

Deskripsi Kategori Variabel dan Persentase

\begin{tabular}{llcccc}
\hline No. & Variabel & Interval & Kategori & $f$ & $\%$ \\
\hline \multirow{2}{*}{ 1. } & \multirow{2}{*}{ Kompetensi } & $1-2$ & Rendah & 0 & 0 \\
& & $2-3$ & Sedang & 12 & 21,43 \\
& & $3-4$ & Tinggi & 44 & 78,67 \\
2. & \multirow{2}{*}{ Motivasi } & $1-2$ & Rendah & 0 & 0 \\
& & $2-3$ & Sedang & 5 & 8,93 \\
& & $3-4$ & Tinggi & 51 & 91,07 \\
3. & Lingkungan & $1-2$ & Rendah & 0 & 0 \\
& Kerja & $2-3$ & Sedang & 6 & 10.71 \\
& & $3-4$ & Tinggi & 50 & 89,28 \\
4. & Kinerja & $1-2$ & Rendah & 0 & 0 \\
& Dosen & $2-3$ & Sedang & 7 & 12,5 \\
& & $3-4$ & Tinggi & 49 & 87,5 \\
\hline
\end{tabular}

Sumber: Data Primer, 2020

Setelah melihat kategori variable, dilakukan Uji Normalitas. Berikut hasilnya:

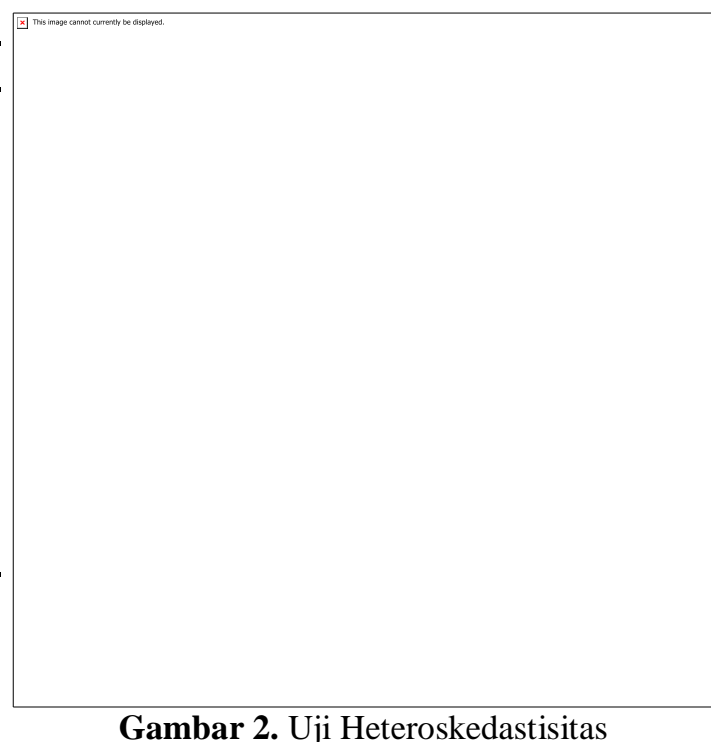

Dari hasil di atas diketahui bahwa nilai signifikansi variabel kompetensi (X1) sebesar 0,750, variabel motivasi (X2) sebesar 0,828 dan lingkungan kerja (X3) sebesar 0,542 yang artinya model regresi terbebas dari heteroskedastisitas 
dikarenakan nilai tersebut lebih besar dari 0,05 .

Setelah Uji heteroskedastisitas, maka dilanjutkan Uji Multikolinearitas yang digunakan untuk mengetahui apakah terdapat korelasi antar variable bebas dan terikat pada model. Berikut hasilnya:

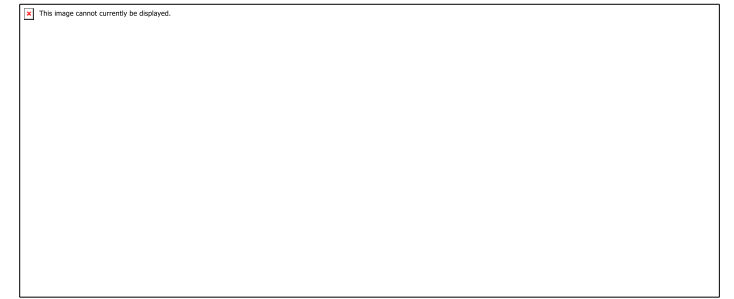

Gambar 3. Uji Multikolinearitas

Berdasarkan hasil di atas, diperoleh nilai tolerance variabel kompetensi sebesar 0,327, motivasi sebesar 0,349 dan lingkungan kerja sebesar 0,564 yang berarti lebih besar dari 0,1 dan juga pada VIF yang ditunjukan oleh variabel kompetensi sebesar 3,056, variabel motivasi sebesar 2,863 dan lingkungan kerja sebesar 1,775 yang menunjukan lebih kecil dari 10, sehingga dapat ditarik kesimpulan bahwa model regresi tidak terjadi multikolinieritas.

Setelah melihat hasil Uji Normalitas Heteroskedastisitas, dan multikolinearitas maka analisis dilanjutkan kepada Uji Hipotesis. Pada Uji ini akan melihat pengaruh variable-variabel independent secara Bersama-sama (simultan) dan secara sendiri-sendiri (parsial) terhadap variable dependen. Yang pertama adalah Uji F. Uji $F$ digunakan utu melihat ada tidaknya pengaruh variabel independen yaitu kompetensi (X1), motivasi (X2) dan lingkungan kerja (X3) terhadap variabel dependen yaitu kinerja dosen (Y) secara bersama-sama. Berikut hasil Uji F:

Gambar 4. Uji F
Dengan Hipotesis sebagai berikut:

$\mathrm{H}_{\mathrm{o}}$ : Kompetensi ( X1) dan motivasi (X2) serta lingkungan kerja (X3) secara bersama-sama tidak berpengaruh terhadap kinerja dosen (Y) di STES Tunas Palapa, Lampug Tengah.

Ha : Kompetensi ( X1) dan motivasi (X2) serta lingkungan kerja (X3) secara bersama-sama berpengaruh terhadap kinerja dosen (Y) di STES Tunas Palapa, Lampug Tengah.

Berdasarkan hasil Uji $\mathrm{F}$ di atas, diperoleh nilai $\mathrm{Sig}=0,000<0,05$. Maka Ho ditolak dan Ha diterima yang artinya kompetensi (X1), motivasi (X2) dan lingkungan kerja (X3) secara bersama-sama berpengaruh terhadap kinerja dosen (Y) di STES Tunas Palapa, Lampung Tengah.

Setelah melakukan Uji F, maka dilanjutkan Uji $\mathrm{T}$ untuk melihat ada tidaknya pengaruh variabel independen yaitu kompetensi (X1) dan motivasi (X2) serta lingkungan kerja (X3) terhadap variabel dependen yaitu kinerja karyawan (Y) secara parsial. Berikut hasil Uji T:

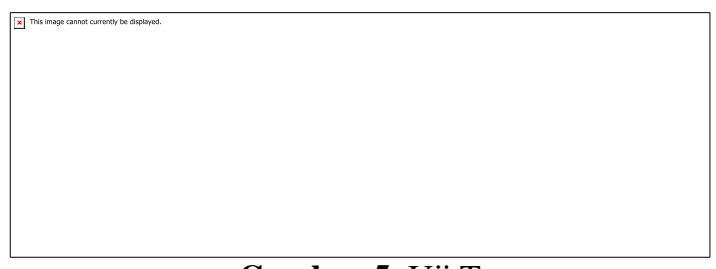

Gambar 5. Uji T

\section{Kompetensi (X1) terhadap Kinerja Dosen (Y)}

Dengan Hipotesis sebagai berikut:

$\mathrm{H}_{\mathrm{o}}$ : kompetensi (X1) tidak berpengaruh terhadap kinerja dosen (Y) STES Tunas Palapa.

$\mathrm{H}_{\mathrm{a}}$ : kompetensi (X1) berpengaruh terhadap kinerja dosen (Y) STES Tunas Palapa.

Berdasarkan Gambar 5 di atas, diperoleh nilai $\mathrm{Sig}=0,000<0,05 . \mathrm{H}_{\mathrm{o}}$ ditolak dan $\mathrm{H}_{\mathrm{a}}$ diterima, yang artinya 
kompetensi (X1) berpengaruh terhadap kinerja dosen (Y) STES Tunas Palapa.

\section{Motivasi (X2) terhadap Kinerja Dosen (Y)}

Dengan Hipotesis sebagai berikut:

$\mathrm{H}_{\mathrm{o}}$ : Motivasi (X2) tidak berpengaruh terhadap kinerja dosen (Y) STES Tunas Palapa.

$\mathrm{H}_{\mathrm{a}}$ : Motivasi (X2) berpengaruh terhadap kinerja dosen (Y) STES Tunas Palapa.

Berdasarkan Gambar 5 di atas, diperoleh nilai $\mathrm{Sig}=0,000<0,05 . \mathrm{H}_{\mathrm{o}}$ ditolak dan $\mathrm{H}_{\mathrm{a}}$ diterima, yang artinya Motivasi (X2) berpengaruh terhadap kinerja dosen (Y) STES Tunas Palapa.

\section{Lingkungan Kerja (X3) terhadap Kinerja Dosen (Y)}

Dengan Hipotesis sebagai berikut:

$\mathrm{H}_{\mathrm{o}}$ : Lingkungan Kerja (X3) tidak berpengaruh terhadap kinerja dosen (Y) STES Tunas Palapa.

$\mathrm{H}_{\mathrm{a}}$ : Lingkungan Kerja (X3) berpengaruh terhadap kinerja dosen (Y) STES Tunas Palapa.

Berdasarkan Gambar 5 di atas, diperoleh nilai $\mathrm{Sig}=0,000<0,05 . \mathrm{H}_{\mathrm{o}}$ ditolak dan $\mathrm{H}_{\mathrm{a}}$ diterima, yang artinya Lingkungan kerja (X3) berpengaruh terhadap kinerja dosen (Y) STES Tunas Palapa.

\section{PENUTUP}

Berdasarkan hasil pengujian hipotesis dapat disimpulkan bahwa: 1) kompetensi ( X1) dan motivasi (X2) serta lingkungan kerja (X3) secara bersama-sama berpenggaruh terhadap kinerja dosen (Y) di STES Tunas Palapa, Lampug Tengah; 2) variable kompetensi (X1) secara parsial berpengaruh terhadap kinerja dosen (Y) STES Tunas Palapa; 3) variabel motivasi
(X2) secara parsial berpengaruh terhadap kinerja dosen (Y) STES Tunas Palapa; dan yang terakhir 4) variable lingkungan kerja (X3) secara parsial berpengaruh terhadap kinerja dosen (Y) STES Tunas Palapa.

Dari kesimpulan di atas, maka timbul beberapa saran, antara lain sangatlah penting bagi seorang dosen untuk memiliki jenjang pendidikan minimal hingga $\mathrm{S}-2$, pengalaman kerja yang memadai, sehingga memiliki pengetahuan, keterampilan dan sikap perilaku yang sesuai dengan mata kuliah yang diampu. Untuk meningkatkan kualifikasinya, maka para dosen juga harus dibekali dengan pelatihan dan pengembangan dosen, sehingga mereka nantinya memiliki lebih banyak pengetahuan dan keterampilan yang sesuai dengan mata kuliah yang diampunya, serta memiliki sikap dan perilaku yang selaras dengan peran dan fungsinya sebagai dosen kejuruan. Selain itu perlu adanya sarana dan prasarana pelengkap dalam kegiatan belajar mengajar yangdapat menambah kinerja seorang dosen dalam memberikan perkuliahan, selain itu juga perlu sikap yang cepat dan tanggap dalam menjadi pihak yang bertanggung-jawab dan tegas dalam memberikan jadwal kegiatan akademik serta memberikan keputusan dan tata tertib.

\section{DAFTAR PUSTAKA}

Adha, R. N., Qomariah, N., \& Hafidzi, A. H. (2019). Pengaruh Motivasi Kerja, Lingkungan Kerja, Budaya Kerja Terhadap Kinerja Karyawan Dinas Sosial Kabupaten Jember. Jurnal Penelitian IPTEKS, 4(1), 47. https://doi.org/10.32528/ipteks.v4i1.2 109

Al-Qadri, Z. (2019). Pengaruh Kompetensi, Kepemimpinan Dan Lingkungan Kerja Terhadap Kinerja Dosen Dan Implikasinya Terhadap Kualitas Lulusan Universitas Abulyatama 
Aceh Besar. ETD Unsyiah.

Aldi, Y., \& Susanti, F. (2019). Pengaruh Stress Kerja Dan Motivasi Kerja Terhadap Prestasi Kerja Karyawan Pada Pt. Frisian Flag Indonesia Wilayah Padang. https://doi.org/10.31227/osf.io/et4rn

Andoyo, A., Muslihudin, M., \& Sari, N. Y. (2017). Pembuatan Model Penilaian Indeks Kinerja Dosen Menggunakan Metode Fuzzy Multi Attribute Decision Making (FMADM) (Studi : PTS di Provinsi Lampung). Prosiding Seminar Nasional Darmajaya, 1(1), 195-205.

Artaye, K., \& Wintoro, P. B. (2017). Sistem Pendukung Keputusan Seleksi Proposal Penelitian Hibah Institusi Menggunakan Simple Additive Weighting. Prosiding Seminar Nasional $\quad$..., 308-315. https://jurnal.darmajaya.ac.id/index.p $\mathrm{hp} / \mathrm{PSND} /$ article/view/784

Asmaroini, A. P. (2016). Implementasi Nilai-Nilai Pancasila Bagi Siswa Di Era Globalisasi. Citizenship Jurnal Pancasila Dan Kewarganegaraan, 4(2), 440. https://doi.org/10.25273/citizenship.v 4i2.1077

Dewi, R. P., Utami, N. I., \& Ahmad, J. (2020). Quality of Work Life Dan Work Engagement Pada Dosen Perguruan Tinggi Swasta Di Yogyakarta. Jurnal Psikologi, 13(1), $15-25$.

https://doi.org/10.35760/psi.2020.v13 i1.2512

Eka, P. D. (2021). Pengaruh Motivasi dan Disiplin Kerja Terhadap Kinerja Karyawan PT. Mega Finance Kantor Pusat Jakarta Selatan. Jurnal Ekonomi Efektif, 3(4), 522-534.

Handayani, W. N., \& Hati, S. W. (2018). Pengaruh Lingkungan Kerja Fisik Terhadap Produktivitas Kerja Karyawan Operator Bagian
Produksipada Perusahaan Manufaktur Di Pt Abc Batam. Aplikasi Administrasi: Media Analisa Masalah Administrasi, 2l(1), 08. https://doi.org/10.30649/aamama.v21i 1.95

Harend, F. maydinda, Isa, R., \& Bokingo, A. H. (2020). Komparasi Kinerja Pegawai Sebelum dan Sesudah Mengikuti Diklat Pada Kantor Wilayah kementerian Hukum dan Hak Asasi Manusia Provinsi Gorontalo. JAMBURA: Jurnal Ilmiah Manajemen Dan Bisnis, 3(1), 7-12.

Hendriana, E. C., \& Jacobus, A. (2017). Implementasi Pendidikan Karakter Di Sekolah Melalui Keteladanan dan Pembiasaan. Jurnal Pendidikan Dasar Indonesia, 1(2), 25-29. https://doi.org/10.32678/tarbawi.v3i0 2.1952

Manik, S., \& Syafrina, N. (2018). Pengaruh Kompetensi Terhadap Kinerja Dosen Sekolah Tinggi Ilmu Ekonomi Riau. Jurnal Ilmiah Ekonomi Dan Bisnis, 15(1), $1-6$. https://doi.org/10.31849/jieb.v15i1.72

Muizu, W. O. Z., \& Sule, E. T. (2017). Manajer Dan Perangkat Manajemen Baru. NASPA Journal, 42(4), 1. (PDF) Jurnal Manajemen Kantor 1 \%7C Feira Dewi Fatmasari Academia.edu

Mukhsin. (2019). JUPE: Jurnal Pendidikan Mandala. JUPE: Jurnal Pendidikan Mandala, 4(5), 276-280.

Mulia, R. A., \& Saputra, N. (2021). Pengaruh Kompetensi Lingkungan Kerja dan Motivasi Berprestasi Terhadap Kinerja Pegawai Negeri Sipil Sekretariat Daerah Kota Padang. Jurnal Ilmiah Ekotrans \& Erudisi, 1(1), 1-24.

Muslihudin, M., Triananingsih, F., \& Anggraei, L. (2017). Pembuatan Model Penilaian Indeks Kinerja Dosen Menggunakan Metode Fuzzy 
Simple Additive Weighting. Semnasteknomedia, 5(1), 25-30.

Muslim, B., Harapan, E., \& Kesumawati, N. (2020). Kepemimpinan Kepala Sekolah dalam Meningkatkan Mutu Pendidikan di SMA Negeri 1 Indralaya Selatan. Jurnal Intelektualitas: Keislaman, Sosial, Dan Sains, 9(1).

Nurmalasari, D. (2019). Student Learning Centre Sebagai Implementasi Program Penugasan Dosen di Sekolah (PDS). Jurnal Pemberdayaan Masyarakat Madani, 3(2), 324-332. https://doaj.org/article/7bf7a969e6bb 42a889b2b60eaffd1d46

Rini, A. S., Istiatin, \& Kustiyah, E. (2018). Pengaruh Kompetensi, Motivasi, Dan Lingkungan Kerja Terhadap Kinerja Karyawan PT Pos Indonesia (Persero) Cabang Surakarta. Program Studi Manajemen Fakultas Ekonomi Universitas Islam Batik Surakarta, 342-351.

Rismayanti, R., Damayanti, F., \& Khairunnisa, K. (2018). Penerapan Data Mining Algoritma C4.5 dalam Menentukan Rekam Jejak Kinerja Dosen STT Harapan Medan. SinkrOn, $3(1)$, 99-104. https://doi.org/10.33395/sinkron.v3i1. 173

Rosmaini, \& Tanjung, H. (2019). Pengaruh Kompetensi, Motivasi Dan Kepuasan Kerja Terhadap Kinerja Pegawai. Maneggio: Jurnal Ilmiah Magister Manajemen, 2(1), 1-15. https://doi.org/10.30596/maneggio.v2 i1.3366

Siagian, T. S., \& Khair, H. (2018). Pengaruh Gaya Kepemimpinan Dan Lingkungan Kerja Terhadap Kinerja Karyawan Dengan Kepuasan Kerja Sebagai Variabel Intervening. Maneggio: Jurnal Ilmiah Magister Manajemen, 1(1), 59-70. https://doi.org/10.30596/maneggio.v1 i1.2241

Sugiono, E., Efendi, S., \& Al-afgani, J. (2021). Kompensasi Terhadap Kinerja Karyawan Melalui Kepuasaan Kerja PT. Wibee Indoedu Nusantara. JIMEA: Jurnal Ilmiah MEA (Manajemen, Ekonomi, Dan Akuntansi), 5(1), 718-734.

Sumardi, D. (2018). Perlindungan Hukum Bagi Pendidik Dalam hukum Pidana Islam. Asy-Syari'ah, 20(1), 35-48.

Sunarsi, D., Wijoyo, H., Prasada, D., \& Andi, D. (2020). Pengaruh Lingkungan Kerja Terhadap Kinerja Karyawan Pada Pt. Hade Dinamis Sejahtera. Seminar Nasional Manajemen, Ekonomi Dan Akuntansi., 5(1), 117-123. https://doi.org/10.37950/wbaj.v2i1.91 6

Teguh, K., \& Julianto, D. (2020). Pengaruh Komitmen Organisasi, Disiplin Kerja Dan Iklim Organisasi Terhadap Kinerja Pegawai Badan Keuangan Daerah Kabupaten Pasuruan. Sasanti: Journal of Economic and Business, 1(1), 52-63. http://ejurnal.stieyapan.ac.id/index.ph p/SAMBA/article/view/111

Wahyudi, W. D., \& Tupti, Z. (2019). Pengaruh Budaya Organisasi, Motivasi dan Kepuasan Kerja Terhadap Kinerja. Maneggio: Jurnal Ilmiah Magister Manajemen, 2(1), 31-44.

https://doi.org/10.30596/maneggio.v2 i1.3363

Winarsih, S. (2018). Gaya kepemimpinan Kepala Sekolah dalam Meningkatkan Kinerja Guru. International Conference of Moslem Society, 2, 95106.

Wulandari, S. (2019). Pengaruh Motivasi Kerja Dan Kemampuan Kerja Terhadap Kinerja Karyawan Stba. Jurnal Lentera Bisnis, 8(1), 95. https://doi.org/10.34127/jrlab.v8i1.26 
2

Yunarti, Y. (2017). Pengaruh Motivasi Kerja Terhadap Kinerja Dosen dan Karyawan Dalam Mengembangkan Sistem Informasi Akademik di STAIN Jurai Siwo. Tapis: Jurnal Penelitian Ilmiah, 1(2), 193-211. 